\title{
A Ganglioside Antigen on the Rat Pancreatic B Cell Surface Identified by Monoclonal Antibody R2D6
}

Rodolfo Alejandro, Frances Litz Shienvold, Shirley A. Vaerewyck Hajek, Michael Pierce, Ronald Paul, and Daniel H. Mintz

Departments of Medicine, Anatomy, and Cell Biology, and Microbiology, University of Miami School of Medicine, Miami, Florida 33101

bstract. In an attempt to identify B cell specific antigens, we have generated a mouse monoclonal antibody, R2D6, which is directed against plasma membranes of rat pancreatic $B$ cells but against no other pancreatic cells. R2D6 crossreacted with mouse and guinea pig B cells, but not with human or dog. The B cell specificity of R2D6 was utilized in fluorescence-activated cell sorting to prepare highly enriched separate populations of viable pancreatic islet B cells and A cells. R2D6 also recognized adrenal chromaffin cells, secretory cells in the anterior pituitary, and the myenteric plexus of the gastrointestinal tract. Trypsin, chymotrypsin, papain, ficin, and pronase had no effect on R2D6-binding to dissociated rat islet cells. However, neuraminidase treatment of intact cells reduced $\mathrm{R} 2 \mathrm{D} 6$-binding by $75 \%$. The antigen recognized by $R 2 D 6, A g(R 2 D 6)$, could be quantitatively extracted from rat islets by dichloromethane/methanol (2:1) and, after drying, was soluble in methanol alone as well as in phosphate-buffered saline. When the dichloromethane/ methanol extract (DME) was bound to polyvinylchloride microtiter plates, antigenic activity was retained and remained insensitive to pronase. In this solvent-extracted form, antigenic activity was totally destroyed by neuraminidase. Therefore, sialic acid is either an integral part of, or is related sterically to the binding site (epitope) for R2D6. In high performance thin-layer chromatographs

This work was presented in part at the 96th Annual Meeting of the Association of American Physicians, Washington, D.C., and at the 23rd Annual Meeting of the American Society for Cell Biology, San Antonio, TX.

Received for publication 17 October 1983 and in revised form 21 March 1984

J. Clin. Invest.

(c) The American Society for Clinical Investigation. Inc. 0021-9738/84/07/0025/14 \$1.00

Volume 74, July 1984, 25-38 of the DME, developed in 60:40:9 chloroform/methanol/ $2.5 \mathrm{~N}$ ammonia, $\mathrm{Ag}(\mathrm{R} 2 \mathrm{D} 6)$ migrated with a relative mobility $\left(R_{f}\right)$ of $0.54 \pm 0.07(n=3)$, which was a position nearly coincident with the purified brain ganglioside, GDla. The antigen bound to DEAE-Sephacel, was not inactivated by mild treatment with base (which hydrolyzes phospholipids) and eluted in ganglioside fractions upon $\mathrm{C}_{18}$ Sep-Pak and upon silicic acid chromatography. Hence, the solubility characteristics, enzyme sensitivities, and behavior of $\mathrm{Ag}(\mathrm{R} 2 \mathrm{D} 6)$ in four chromatography systems are consistent with its identification as a ganglioside.

\section{Introduction}

The coexistence with insulin-dependent diabetes mellitus (IDDM) ${ }^{1}$ of an autoimmune process directed against pancreatic islets of Langerhans has been well documented. Islet cell surface antibodies are immunocytochemically detectable in the sera of $67-82 \%$ of recent-onset IDDM patients (1-3). Islet cell surface antibodies can be cytotoxic to B cells (4) and may alter glucosestimulated insulin release (5), so that these circulating autoantibodies may be direct effectors of B cell destruction in IDDM or, instead, reflect some other unknown pathogenetic mechanism.

The problem of identifying B cell specific antigens, i.e., cell surface molecules of potential significance in the autoimmune pathogenesis of IDDM, has not yet been successfully approached. In an attempt to identify target antigens that were recognized by islet cell antibodies, Baekkeskov et al. (6) did immunoprecipitate 64,000 - and $38,000-\mathrm{mol}$ wt proteins from human islet preparations using sera from patients with IDDM. However, it was not shown that the antigens precipitated were specific either

1. Abbreviations used in this paper: $\mathrm{CB}$, cacodylate buffer, $\mathrm{pH}$ 7.4, DME, dichloromethane/methanol extract; FCS, fetal calf serum; FITC, fluorescein isothiocyanate; FACS, fluorescence-activated cell sorting; HPTLC, high performance thin-layer chromatography; IDDM, insulin-dependent diabetes mellitus; MEM, minimum essential medium; PVC, polyvinylchloride. 
for endocrine cells or for the cell surface. An alternative approach is to generate mouse monoclonal antibodies against islet cells. Although two monoclonal antibodies that recognize pancreatic islet cells have been generated previously by Eisenbarth et al. (7-9), one (A2B5) was raised against glutaraldehyde-fixed chicken embryo retinal cells, whereas the other (A1D2) was produced using a rat islet-cell tumor cell line, RINm5F, as the immunogen. These monoclonal antibodies are not B cell specific within the pancreas, since they recognize plasma membrane determinants shared by B, A, and D cells of pancreatic islets (reference 9, and present study).

In the present study, we report on the generation and characterization of a monoclonal antibody, R2D6, raised against normal Wistar-Furth islet cells, which recognizes a $B$ cell specific plasma membrane ganglioside antigen. We also report on the utilization of this antibody for purification of pancreatic B and A cells by fluorescence-activated cell sorting.

\section{Methods}

Sources. Reagents were obtained from the following sources: culture medium RPMI 1640, Ham's F-10, Dulbecco's PBS, fetal calf and horse serum, antibiotic-antimycotic mixture, glutamine, and trypsin from Gibco Laboratories (Grand Island, NY); minimum essential medium (MEM), NCTC 109, NEAA (nonessential amino acids), and sodium pyruvate from M. A. Bioproducts (Walkersville, MD); hypoxanthine, thymidine, aminopterin, bovine insulin, bovine serum albumin (fraction V; BSA), oxaloacetic acid, bovine DNase (DN-25), EGTA, and sodium azide $\left(\mathrm{NaN}_{3}\right.$ ) from Sigma Chemical Co. (St. Louis, MO); polyethylene glycol 1,000 from J. T. Baker Chemical Co. (Phillipsburg, NJ); and 26-10-14-tetramethylpentadecane (Pristane) from Aldrich Chemical Co., Inc. (Milwaukee, WI); Araldite from Ladd Research Industries, Inc. (Burlington, VT); specific rabbit antibodies to mouse $\mathrm{IgG}_{1}, \mathrm{IgG}_{2 \mathrm{~b}}, \mathrm{IgG}_{3}$, IgM heavy chains, or to lambda or kappa light chains from Litton Bionetics Inc. (Charleston, SC); fluorescein- and peroxidase-conjugated goat anti-mouse immunoglobulins from Cappel Laboratories Inc. (Cochranville, PA); rabbit complement (Low-Tox-H) from Accurate Chemical \& Scientific Corp. (Westbury, NY); ${ }^{125} \mathrm{I}$-labeled $\mathrm{F}\left(\mathrm{ab}^{\prime}\right)_{2}$ fragments of sheep anti-mouse immunoglobulins, sodium chromate $\left({ }^{51} \mathrm{Cr}\right)$ and $\mathrm{Na}^{125}$ I from New England Nuclear (Boston, MA); Ficoll-Paque and Sephacryl S-300 Superfine from Pharmacia Fine Chemicals (Piscataway, $\mathrm{NJ}$ ); all proteases from Boehringer Mannheim (Indianapolis, IN); neuraminidase from Vibro cholerae (protease-, aldolase-, and lecithinasefree) from Calbiochem-Behring Corp. (San Diego, CA); Merck Silica Gel 60 high performance thin-layer chromatography plates (HPTLC) from Applied Analytical Industries (Wilmington, NC); Bio-Sil HA from Bio-Rad Laboratories (Richmond, CA); $\mathrm{C}_{18}$ Sep-Pak from Waters Associates (Milford, MA); DEAE-Sephacel and Sephadex. LH-20 from Pharmacia Fine Chemicals; and disialoganglioside (GDla), trisialoganglioside (GT1b), and mixed brain gangliosides were from Supelco, Inc. (Bellefonte, PA).

Adult Wistar-Furth and Lewis rats were obtained from M.A. Bioproducts; BALB/c mice from Charles River Breeding Laboratories, Inc. (Wilmington, MA); normal adult beagles from Marshall Research Animals (North Rose, NY); and guinea pigs were from local suppliers. The $\mathrm{GH}_{3}$ cell line and clone A2B5 were obtained from the American Type
Culture Collection (Rockville, MD). The SP2/0-Ag14 cell line was a gift from Dr. M. Carreno, Department of Medicine, University of Miami, FL. The cell line RINm5F was a gift from Dr. G. S. Eisenbarth (Joslin Diabetes Center, Research Division, Boston, MA).

Cell culture. The SP2/0-Ag14 mouse plasmacytoma cell line (10) was maintained in MEM with $4.5 \mathrm{~g}$ glucose/l that was supplemented with $10 \%$ fetal calf serum (FCS) and with $1 \%$ antibiotic-antimycotic mixture. Clones obtained from fusions were also maintained in this medium. The rat insulinoma cell line (RINm5F), the clone A2B5, and a primary rat skin fibroblast cell line, which was established in our laboratory from Wistar-Furth skin, were propagated in RPMI-1640 medium that was supplemented with $10 \%$ FCS and with $1 \%$ antibioticantimycotic mixture. The rat pituitary tumor, somatotropin-secreting cell line $\left(\mathrm{GH}_{3}\right)$, was propagated in Ham's F-10 medium which was supplemented with $15 \%$ horse serum and $2.5 \%$ FCS.

Tissue sources. Wistar-Furth and Lewis adult rats weighing $\sim 120$ $125 \mathrm{~g}$ served as the source of pancreas, thyroid, adrenal, pituitary, thymus, stomach, small intestine, spleen, and brain. BALB/c mice, 6-8-wk-old, adult guinea pigs, and normal adult beagles served as donors of pancreases. Human type-O pancreases were obtained from heart-beating cadavers at the time that kidneys were retrieved for organ transplantation. Rat leukocytes and erythrocytes were isolated from homogenized spleen by Ficoll-Paque density gradient centrifugation (11).

Isolation of pancreatic islets. Rat islets were isolated from WistarFurth rats weighing $\sim 120-125 \mathrm{~g}$ using the collagenase digestion method of Lacy and Kostianovsky (12). For some cell-sorting experiments, less pure islet fractions were prepared by retrieving tissue from the third density interface of the Ficoll gradient in addition to the upper two interfaces. This method allowed us to increase islet recovery and to simultaneously test whether cell sorting could yield populations of equivalent purity regardless of the diversity of the starting populations.

Preparation of single islet cell suspensions. Rat islets were dissociated by the method described by Meda et al. (13) which combines EGTA, trypsin, and mechanical shear. This procedure yields a predominantly (80-95\%) single cell preparation with viabilities of $75-90 \%$, as assessed by fluorescein diacetate staining.

Production of monoclonal antibodies. Female BALB/c mice (6-8wk-old) were immunized by intraperitoneal injection of partially dispersed, cultured (12-18 h) Wistar Furth islet cells. $10^{6}$ cells were injected on days $0,52,66$, and 89 , and $3 \times 10^{6}$ cells injected on day $107.3 \mathrm{~d}$ after the last booster, the splenocytes of two immunized mice were harvested and fused by a modification of the procedure described by Galfre and Milstein (14). The fusion was carried out in the presence of polyethylene glycol 1,000 with the mouse myeloma cell line SP2/0 at a ratio of 5:1 (splenocytes: SP2/0). The treated cells were suspended in selective hypoxanthine/aminopterin/thymidine medium (15) and distributed in 96-well tissue culture plates $(400,000$ cells in $150 \mu \mathrm{l} /$ well). $1 \mathrm{wk}$ after the fusion, supernatants from wells containing growing hybrids were removed for cell-binding assays against dispersed rat islet cells. Positive wells were expanded and rescreened against rat islet cells, splenic leukocytes, skin fibroblasts, and erythrocytes.

A hybrid that demonstrated exclusive binding to rat islet cells was cloned twice by the limiting dilution method $(0.3$ cells/well $)$ in hypoxanthine-thymidine medium (16), which resulted in a statistical probability of monoclonality of $99 \%$ (17). Normal BALB/c splenic leukocytes were used as feeder cells $\left(10^{5}\right.$ cells $\left./ \mathrm{ml}\right)$. The resulting clone was termed R2D6-5.3, and will be referred to as R2D6.

Large amounts of monoclonal antibodies were produced by the induction of ascites in Pristane-primed BALB/c mice. Monoclonal anti- 
bodies R2D6, A2B5, and the irrelevant antibodies B5C2 and A5H5 (all belong to the IgM isotype) were precipitated with $50 \%$ saturated ammonium sulfate (18) and, after extensive dialysis against $0.5 \mathrm{M} \mathrm{NaCl}$, 0.05 Tris-HCL ( $\mathrm{pH} 8.0$ ), were partially purified by gel filtration chromatography on Sephacryl S-300 Superfine.

\section{Antibody-Binding Assays}

(a) Cell binding. The binding of monoclonal antibodies to single cells was performed as described $(19,20) .50 \mu l$ of the cell suspension $(2-5$ $\times 10^{5}$ cells) in Dulbecco's PBS, $1 \% \mathrm{BSA}$, and $0.02 \% \mathrm{NaN}_{3}$ (radioimmunoassay [RIA] buffer) were incubated at room temperature for 30 min with $50 \mu \mathrm{l}$ of diluted antibody $(10 \mu \mathrm{g} / \mathrm{ml})$ in polyvinylchloride (PVC) microtiter plates. Cells were then washed three times by centrifugation and $50 \mu \mathrm{l}$ of ${ }^{125}$-labeled $\mathrm{F}\left(\mathrm{ab}^{\prime}\right)_{2}$ fragments of sheep antimouse immunoglobulins $(200,000 \mathrm{cpm})$ were added. After incubation at room temperature for $30 \mathrm{~min}$, the cells were washed three times and wells were cut with a hotwire cutter device and assayed for radioactivity in a gamma counter.

(b) Direct-blocking assays. Purified monoclonal antibody R2D6 (290 $\mu \mathrm{g}$ ) and $\mathrm{A} 2 \mathrm{~B} 5$ ascites ( $50 \mu \mathrm{l}$ of 1:100 dilution) were radiolabeled by the chloramine-T method (19). The labeled antibodies were then assayed for retention of antibody specificity. The inhibition of binding of ${ }^{125} \mathrm{I}-$ labeled R2D6 or ${ }^{125}$ I-labeled A2B5 to rat islet cells $(100,000$ cells/well $)$ by unlabeled antibodies R2D6, A2B5, and B5C2 (an irrelevant monoclonal IgM) was performed as described above.

(c) Solid phase. To test whether the monoclonal antibodies recognize insulin or glucagon, or to determine monoclonal antibody subclasses, insulin or glucagon, or specific rabbit antibodies to mouse $\operatorname{IgG}_{1}, \mathrm{IgG}_{2 \mathrm{a}}$, $\operatorname{IgG}_{2 b}, \operatorname{lgG}_{3}$, or IgM heavy chains, or to lambda or kappa light chains, were bound to PVC microtiter plates as described (14). The radioimmunobinding assay was performed as previously described except that centrifugation was not required.

Light microscopic immunocytochemistry. Cryostat sections $(5 \mu \mathrm{m}$ thick) from fresh frozen organs were transferred to gelatinized slides and fixed with acetone for $1 \mathrm{~min}$ at $4^{\circ} \mathrm{C}$ and then air dried. Sections were incubated with diluted R2D6 or A5H5 ascites (1:100), or with diluted purified antibodies $(100 \mu \mathrm{g} / \mathrm{ml}, 0.01 \mathrm{M}$ phosphate $/ 0.15 \mathrm{M} \mathrm{NaCl}$ buffer, $\mathrm{pH} 7.4$ [PBS]) at room temperature for $30 \mathrm{~min}$, washed three times with PBS, and then incubated with a 1:50 dilution of fluoresceinconjugated goat anti-mouse immunoglobulins. After washing, the sections were mounted in $4 \%$ paraformaldehyde-PBS and examined for fluorescence with a Zeiss microscope that was equipped for epi-illumination with a xenon light source and with fluorescein barrier filters.

Cell sorting. A single cell suspension of rat islet cells $\left(2-4 \times 10^{6}\right.$ cells) in $500 \mu$ l of supplemented RPMI (RPMI- 1640 with $0.1 \%$ heatinactivated $\mathrm{FCS}, 0.1 \%$ heparin, $10 \mathrm{mg} \mathrm{DNase} / \mathrm{ml}, 100 \mathrm{U}$ potassium penicillin $\mathrm{g} / \mathrm{ml}, 100 \mu \mathrm{g}$ streptomycin sulfate $/ \mathrm{ml}$, and $1.25 \mu \mathrm{g}$ amphotericin $\mathrm{B} / \mathrm{ml}$ ) was incubated at $4^{\circ} \mathrm{C}$ for $30 \mathrm{~min}$ with $500 \mu \mathrm{l}$ of a 1:50 dilution of R2D6-ascites fluid or with an irrelevant monoclonal antibody. The cells were washed and centrifuged ( $150 \mathrm{~g}$ for $8 \mathrm{~min}$ ) twice with supplemented RPMI and then were incubated with $500 \mu$ l of a 1:50 dilution of fluorescein-conjugated goat anti-mouse immunoglobulins at $4^{\circ} \mathrm{C}$ for 30 min. After washing, cells were resuspended in Dulbecco's PBS, which was supplemented as described above for RPMI. Total cell number, viability, and percentage of cells demonstrating surface fluorescence were then determined by light microscopy.

Flow cytometry and sorting were performed on a fluorescence-activated cell sorter (FACS III; Becton-Dickinson, FACS Div., Sunnyvale, CA). Chicken erythrocytes rendered fluorescent by glutaraldehyde fixation were used for scatter and fluorescence standardization of the machine. The argon ion laser beam was set at $488 \mathrm{~nm}$ for maximum excitation of fluorescein isothiocyanate (FITC) bound to labeled cells. Analysis and sorting of R2D6-positive or R2D6-negative populations were based on scattergating of the entire islet cell population and on the difference in fluorescent intensity expressed by cells labeled by indirect immunofluorescence with R2D6 compared with an irrelevant antibody. Separation was accomplished using a two-way sorting technique in which fluorescent (R2D6-positive) cells were deflected in one direction and nonfluorescent (R2D6-negative) cells were deflected in the opposite direction.

Electron microscopy of sorted cells. When sorting was completed, cells were pelleted by centrifugation at $200 \mathrm{~g}$ for $10 \mathrm{~min}$. The pellet was then resuspended in $2.5 \%(\mathrm{w} / \mathrm{v})$ glutaraldehyde in Dulbecco's PBS for $20 \mathrm{~min}$ at room temperature. The cells were then repelleted and washed in $0.1 \mathrm{M}$ cacodylate buffer, $\mathrm{pH} 7.4(\mathrm{CB})$, postfixed in $2 \%(\mathrm{w} / \mathrm{v}) \mathrm{OsO}_{4}$ in $\mathrm{CB}$ for $1 \mathrm{~h}$, washed in $\mathrm{CB}$, dehydrated through a graded ethanol series and propylene oxide, and then were embedded in Araldite. Silver sections were cut on a diamond knife, mounted on carboncoated copper slotgrids, and were stained with uranyl acetate followed by lead citrate. All cells in each section were photographed, using a Philips 301 electron microscope (Philips Electronic Instruments, Mahwah, NJ) at $60 \mathrm{kV}$ with a $30 \mu \mathrm{m}$ objective aperture. Montages of each section were then constructed and used to classify celltypes based on the ultrastructural characteristics of the secretory granules. Each ultrathin section that was analyzed was at least $20 \mu \mathrm{m}$ from any other section from the same block and sections were taken throughout the thickness of each block. These methods of analysis ensured that no cell was counted more than once and that the entire pellet was sampled.

Chromium $\left({ }^{51} \mathrm{Cr}\right)$ release assay. The ${ }^{51} \mathrm{Cr}$ release assay was performed as described (21) after minor modifications. Cells were labeled with ${ }^{51} \mathrm{Cr}$ by incubating $2-5 \times 10^{6}$ cells with $200 \mu \mathrm{Ci}{ }^{51} \mathrm{Cr}$ at $37^{\circ} \mathrm{C}$ for $1 \mathrm{~h}$. After washing the cells, the pellet was suspended to $\sim 100,000$ cells $/ 50 \mu \mathrm{l}$ and $50 \mu$ l of diluted R2D6 ascites (1:20) or an irrelevant monoclonal antibody ascites A5H5 (1:20) were added. The plates were incubated at room temperature for $60 \mathrm{~min}$, washed, and reincubated with $50 \mu \mathrm{l}$ of a 1:3 dilution of rabbit complement at $37^{\circ} \mathrm{C}$ in $5 \% \mathrm{CO}_{2}$ for an additional 60 min. $150 \mu \mathrm{l}$ of fresh MEM was then added, and after centrifugation the supernatant was harvested with a Titertek collection system and counted in a gamma counter. The percentage of specific chromium release was then calculated.

Electron microscopic immunocytochemistry. The antigen recognized by R2D6 was localized by indirect immunoperoxidase labeling of islets using a modification of previously published procedures (22). Freshly isolated islets were partially dispersed to allow adequate access of antibodies to all cell surfaces, and then washed free of serum in RPMI1640. Cells from 100 islets were then incubated $45 \mathrm{~min}$ at room temperature in $30 \mu$ l diluted R2D6 ascites (1:5 in RPMI-1640 containing $0.02 \% \mathrm{NaN}_{3}$ ). Controls consisted of islet cells incubated in media containing either no antibody or an irrelevant monoclonal IgM antibody, A5H5. All samples were washed three times in RPMI/ $/ \mathrm{NaN}_{3}$ and then incubated for $45 \mathrm{~min}$ in $30 \mu$ diluted peroxidase-conjugated goat antimouse immunoglobulins (1:5 in $\mathrm{RPMI} / \mathrm{NaN}_{3}$ ). The cells were next washed three times in $\mathrm{RPMI} / \mathrm{NaN}_{3}$, fixed in $2.5 \%$ glutaraldehyde/0.1 $M$ sodium CB, and then washed three times in $0.1 \mathrm{M} \mathrm{CB}$. The diaminobenzidine reaction was then carried out to allow ultrastructural localization of antibody binding. All samples were then washed, postfixed, dehydrated, embedded, and sectioned, as described above for sorted cells. Sections were photographed unstained in a Philips 301 electron 
microscope (Philips Electronic Instruments) at $60 \mathrm{kV}$ with a $30-\mu \mathrm{m}$ objective aperture.

\section{Antigen identification}

Enzyme sensitivities. Dispersed islet cells $(750,000-900,000)$ were incubated at $37^{\circ} \mathrm{C}$ for $15 \mathrm{~min}$ (with shaking) with $500 \mu \mathrm{g}$ enzyme $/ \mathrm{ml}$ PBS for pronase ( $\mathrm{pH} 7.5$ ), papain ( $\mathrm{pH} 7.0$ or 6.0), trypsin ( $\mathrm{pH} \mathrm{7.5),} \mathrm{ficin} \mathrm{(} \mathrm{pH}$ 6.0 ), or chymotrypsin (pH 7.4), or for $1 \mathrm{~h}$ with protease-, aldolase-, and lecithinase-free neuraminidase ( $1 \mathrm{U} / \mathrm{ml}$ PBS, $\mathrm{pH}$ 6.0). Control incubations were performed with buffer at the same $\mathrm{pH}$ as each enzyme. All cells were washed three times in RIA buffer and R2D6-binding was assessed in a cell-binding assay as described above.

Immunoadsorption of radiolabeled islet proteins. Rat islet cell surface proteins were radioiodinated by the method of Hubbard and Cohn (23), or cellular proteins were labeled metabolically by ${ }^{35} \mathrm{~S}$-methionine incorporation after the method of Hughes and August (24). Labeled membrane proteins were then solubilized in NP40, immunoadsorbed with R2D6, using the method of Lampson (25), and then analyzed by SDS polyacrylamide gel electrophoresis (26).

Immunoblotting of unlabeled islet protein. Unlabeled rat islet cell proteins were subjected to SDS-polyacrylamide gel electrophoresis (under nonreducing conditions), which was followed by electrophoretic transfer to nitrocellulose paper and by immunoautoradiographic detection of antigens with R2D6; the methods developed by Erickson et al. (27) were used.

Solvent extraction. Islets were washed in PBS and then homogenized as a pellet with three rapid passes of a 1-ml Thomas Teflon pestle homogenizer (100 $\mu \mathrm{m}$ clearance). The homogenate was then extracted with 2:1 (v/v) chloroform/methanol $(2 \mathrm{ml} / 4,000$ islets $)$ and sonicated in a Labline Ultratip sonicator (model 9100) at maximum power for $15 \mathrm{~s}$. The extracted islets were pelleted at $2,000 \mathrm{~g}$ for $10 \mathrm{~min}$, the supernatant saved, and the pellet was reextracted twice ( $1 \mathrm{ml} / 4,000$ islets). The three supernatants were pooled, dried under nitrogen gas, and immediately redissolved (with sonication) in either methanol or PBS, pH $7.4\left(50 \mu \mathrm{l} /\right.$ extract from 100 islets) and stored at $4^{\circ} \mathrm{C}$. All steps were performed in glass vessels. Dichloromethane was used instead of chloroform after preliminary studies showed that R2D6-binding properties of the dried and redissolved dichloromethane/methanol extract (DME) were indistinguishable from those of the chloroform/methanol extract. The DME was adsorbed to PVC plates $\left(37^{\circ} \mathrm{C}\right.$ for $\left.1 \mathrm{~h}\right)$ and tested for R2D6-binding by solid-phase RIA as described above. The adsorbed DME was also tested for enzyme sensitivity of R2D6-binding. DME was adsorbed to PVC microtiter wells as above and then incubated with either Pronase $(500 \mu \mathrm{g} / \mathrm{ml}$ PBS, $\mathrm{pH} 7.4)$ at $60^{\circ} \mathrm{C}$ for $24 \mathrm{~h}$, neuraminidase (1 U/ml PBS, pH 6.0) at $37^{\circ} \mathrm{C}$ for $2 \mathrm{~h}$, or appropriate buffer controls.

Chromatography. The DME was subjected to mild base hydrolysis and was fractionated on a C-18 Sep-Pak reverse-phase high performance liquid chromatography cartridge using the method described by Kundu and Suzuki (28). The hydrolysate was applied to the cartridge in water, washed with methanol, and the ganglioside fraction was eluted with chloroform/methanol (2:1). DEAE-Sephacel chromatography was performed by the method of Magnani (29). The DME was applied to the column $(1 \times 2 \mathrm{~cm})$ in chloroform/methanol/water (30:60:8). The column was washed with $50 \mathrm{ml}$ of solvent and the ganglioside fraction was eluted with $20 \mathrm{ml}$ of $0.2 \mathrm{M}$ ammonium acetate in methanol. The pooled void volume fractions and acetate fractions were separately concentrated. The acetate fractions were desalted on a Sephadex LH-20 column $(0.5$ $\times 10 \mathrm{~cm}$ ) in methanol and each 2-ml fraction was dried under $\mathrm{N}_{2}$. The pooled DEAE void fractions and each LH-20 fraction were then tested for binding activity using the solid-phase assay. All activity was recovered in the LH-20 void fractions. Silicic acid chromatography was performed also by the method of Magnani (29). A $(0.5 \times 2 \mathrm{~cm})$ column of BioSil HA was washed with $100 \mathrm{ml}$ of chloroform/methanol (2:1) and the DME was applied in the same solvent. The column was washed with $20 \mathrm{ml}$ of solvent and the ganglioside fraction was eluted with $20 \mathrm{ml}$ methanol. The void and methanol fractions were separately pooled, evaporated, and assayed for binding activity. In all three fractionation experiments, $0.1 \mathrm{mg}$ of mixed brain gangliosides was added to the DME as carrier. High performance thin-layer chromatography plates were prerun, before sample loading, in the developing solvent (60:40:9 chloroform/methanol/2.5 N ammonia) and were dried thoroughly. DME from 200 rat islets was dried under nitrogen gas, redissolved (with sonication) in $10 \mu \mathrm{l} \mathrm{chloroform} / m e t h a n o l ~(2: 1)$, and spotted across a 5-mm line $(200 \mathrm{nl} / \mathrm{spot})$ which was $1.0 \mathrm{~cm}$ from the bottom edge of an HPTLC plate that was then developed. The separation was terminated when the solvent front was 2-3 $\mathrm{mm}$ from the top of the plate. The plate was divided into $5-\mathrm{mm}$ sections ( $1.5 \mathrm{~cm}$ wide), and each section of silica gel was scraped. Each section was suspended by sonication in $400 \mu \mathrm{l}$ methanol. The silica gel was removed by filtration through a Millex GV filter. The eluted samples were dried, redissolved, and sonicated in 200 $\mu \mathrm{l}$ methanol, and adsorbed onto PVC wells $(50 \mu \mathrm{l} /$ well) for solid-phase RIA of R2D6-binding activity, as described above. Purified brain gangliosides were used as standards by spotting $5 \mu \mathrm{g}$ in parallel lanes on the HPTLC plate. After development, the plate was broken in half and the side containing the standards was stained with $\mathbf{I}_{2}$.

Glucose-stimulated insulin release. Adult Wistar-Furth pancreatic islets, isolated by collagenase digestion, were preincubated at $5.6 \mathrm{mM}$ glucose in TCM199 medium for $18 \mathrm{~h}$. Washed batches of 10 islets/3.5$\mathrm{mm}$ dish were then incubated in 5.6 or $16.5 \mathrm{mM}$ glucose with B5C2 (an irrelevant antibody) or R2D6 for $2 \mathrm{~h}$. Insulin released into media was determined by RIA. In order to ensure adequate access of R2D6 to B cell surfaces, we performed similar experiments using monolayer cultures of rat islets. Adult Wistar-Furth islets were also dispersed by trypsin $(0.1 \%) / E G T A(3 \mathrm{mM})$ into single cells and plated $(20,000$ cells/ 135 -mm tissue culture dish) in TCM 199, which contained $11 \mathrm{mM}$ glucose and $0.1 \mathrm{mM}$ 3-isobutyl-1-methylxanthine. The single cells reaggregated and formed monolayers after $4 \mathrm{~d}$, and these were used to determine whether R2D6 affected glucose-mediated insulin release.

\section{Results}

Production of monoclonal antibody R2D6. The spleen cells from $\mathrm{BALB} / \mathrm{c}$ mice that were immunized with Wistar-Furth islet cells were fused with the myeloma cell line SP2/0-Ag14. Initial screening of culture supernatants from the resulting hybridomas was performed on Wistar-Furth islet cells, rat skin fibroblasts, RINm5F cells, rat splenic leukocytes, and rat red blood cells by cell-binding RIA. One hybridoma showed binding to islet cells alone and was cloned twice by limiting dilution. The resulting clone was designated R2D6-5.3 and will be referred to as R2D6. After rescreening this clone to confirm its specificity, as described above, the clone was expanded in culture and then injected into Pristane-primed mice to induce ascites fluid formation. The R2D6 isotype was identified as $\operatorname{IgM(k)}$ by solidphase RIA. Partially purified antibodies or ascites were used as the source of antibodies for the experiments described in this report. 


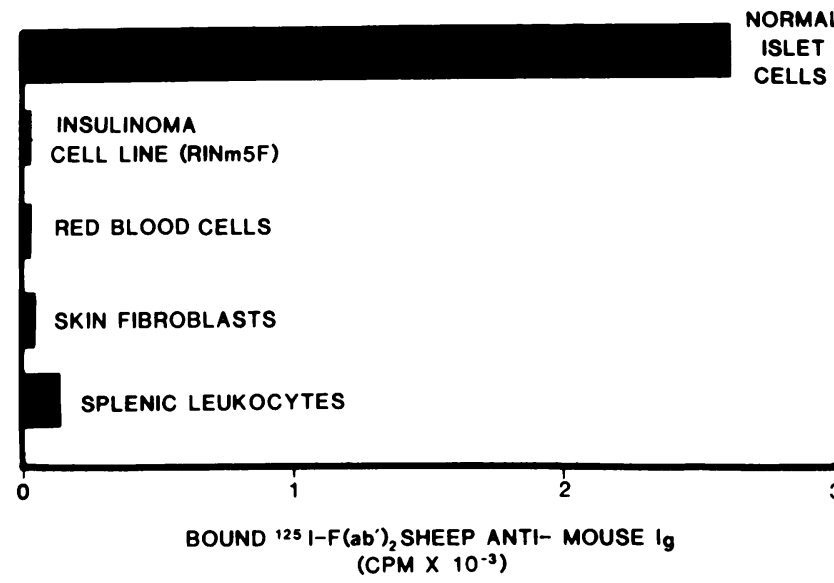

Figure 1. Cell-binding RIA of R2D6 binding to different rat cell types for a representative experiment. Cells $(250,000 /$ well $)$ were incubated with purified R2D6 ( $0.5 \mu \mathrm{g}$ in $50 \mu \mathrm{l} /$ well) followed by incubation with ${ }^{125}$ I-labeled sheep $F\left(a b^{\prime}\right)_{2}$ fragments that were directed against mouse immunoglobulins $(200,000 \mathrm{cpm}$ in $50 \mu \mathrm{l} /$ well). The horizontal axis shows the mean $\mathrm{cpm}$ of triplicate determinations for bound ${ }^{125}$ I-labeled $\mathrm{F}\left(\mathrm{ab}^{\prime}\right)_{2}$ after the binding of a nonspecific antibody, $P_{3}$, was subtracted. The standard error of these triplicate determinations was $<10 \%$ of the mean value in each instance.

$R 2 D 6$ binding characteristics and cytotoxicity. The binding of R2D6 to different rat cell-types, assessed by RIA, is shown in Fig. 1. R2D6 bound to rat islet cells from a variety of strains, including Wistar-Furth, Sprague-Dawley, and Lewis. It did not bind rat splenic leukocytes, red blood cells, skin fibroblasts, or the rat insulinoma cell line, RINm5F. R2D6 also did not bind to either insulin or glucagon. In standard chromium release assays, R2D6 was highly cytotoxic to rat islet cells in comparison to an irrelevant IgM monoclonal antibody, A5H5 (data not shown).
Glucose-stimulated insulin release after R2D6-binding. Adult rat islets were incubated in 5.6 or $16.5 \mathrm{mM}$ glucose with R2D6 or P3, and insulin that was released into the media was determined by RIA. R2D6 did not alter glucose-mediated insulin release under these conditions. In order to ensure adequate access of R2D6 to B cell surfaces, we performed similar experiments using monolayer cultures of adult rat islets. R2D6 still had no effect on insulin release in response to glucose. R2D6-binding to the cell surfaces of these monolayer cultures was confirmed by immunofluorescence.

Direct-blocking assays. The relationship of the antigenic determinants recognized by the monoclonal antibodies R2D6 and A2B5 was assessed by reciprocal direct-blocking assays. As shown in Fig. 2 (left), unlabeled A2B5, but not R2D6, blocked the binding of ${ }^{125} \mathrm{I}-\mathrm{A} 2 \mathrm{~B} 5$ to dissociated rat islet cells. Unlabeled R2D6 and unlabeled A2B5 both blocked the binding of ${ }^{125} \mathrm{I}$ R2D6 to dissociated rat islet cells (Fig. 2, right). An irrelevant monoclonal antibody, B5C2, did not block the binding of either ${ }^{125} \mathrm{I}-\mathrm{A} 2 \mathrm{~B} 5$ or ${ }^{125} \mathrm{I}-\mathrm{R} 2 \mathrm{D} 6$.

Light and electron microscopic immunocytochemistry. Indirect immunofluorescence studies of cryostat section rat pancreas revealed that R2D6 binds to islets of Langerhans but not to other pancreatic cells (Fig. 3). R2D6 also recognized mouse and guinea pig islets, but not human or dog islets. Living, dispersed rat islet cells labeled with R2D6 by indirect immunofluorescence exhibited a pattern of rim fluorescence, which suggested a cell surface localization for the antigen recognized by R2D6. In order to identify the precise localization of R2D6 on cells within the pancreatic islets, we labeled unfixed rat islets by indirect immunoperoxidase for electron microscopy. Electron microscopic examination revealed that R2D6 heavily labels the B cell plasma membranes (Fig. 4), but not those of A and D cells, nor of pancreatic acinar or ductal cells. By contrast, A2B5 binds to the plasma membranes of $A$ and $D$ cells as well as to B cells (Fig. 5). Control preparations, in which the islets were

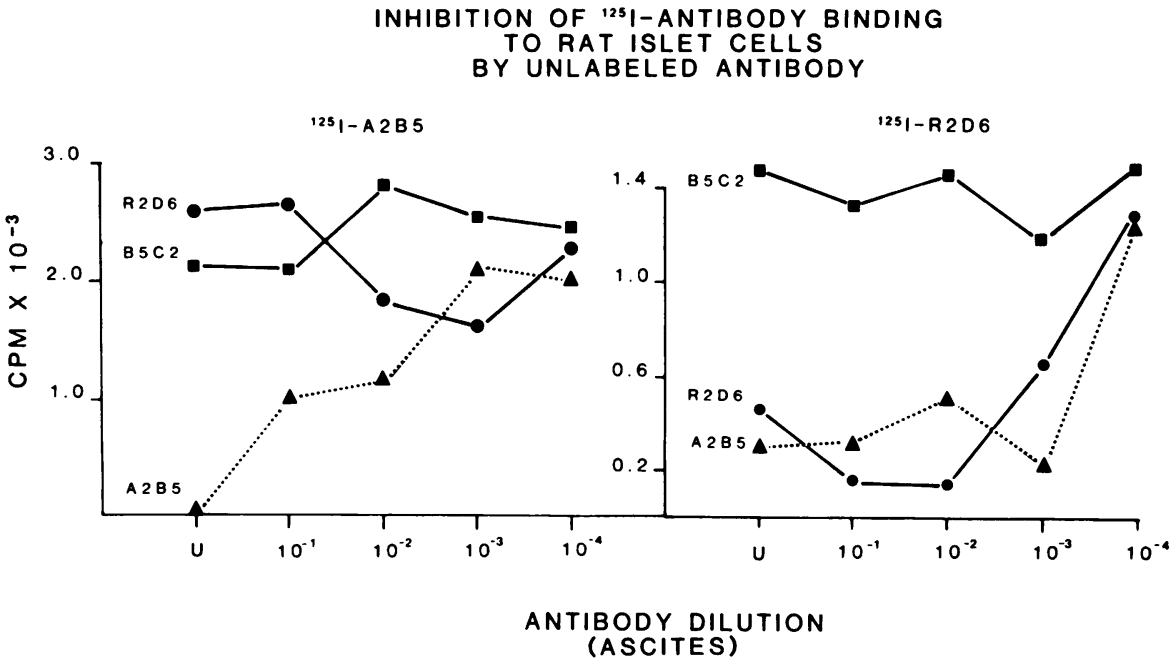

Figure 2. Direct blocking assays, R2D6 vs. A2B5. Inhibition of the binding of ${ }^{125} \mathrm{I}$-labeled A2B5 or ${ }^{125}$ I-labeled R2D6 to rat islet cells by unlabeled R2D6, A2B5, and B5C2 (B5C2 is an irrelevant monoclonal IgM) is shown. Cells $(100,000 /$ well $)$ were incubated with diluted antibodies (from ascites) in PVC microtiter plates for $30 \mathrm{~min}$, washed, incubated with ${ }^{125}$ I-labeled antibody $(240,000 \mathrm{cpm} /$ well) for $30 \mathrm{~min}$, and were washed again. The wells were cut and assayed for bound radioactivity. Results are expressed on the ordinate as the mean value $(n=3) \mathrm{cpm}$ of ${ }^{125} \mathrm{I}$-antibody that was bound after the nonspecific binding of ${ }^{125} \mathrm{I}$ antibody to empty wells was substracted. The dilution of ascites is expressed on the abscissa. $\mathrm{U}$, undiluted. 

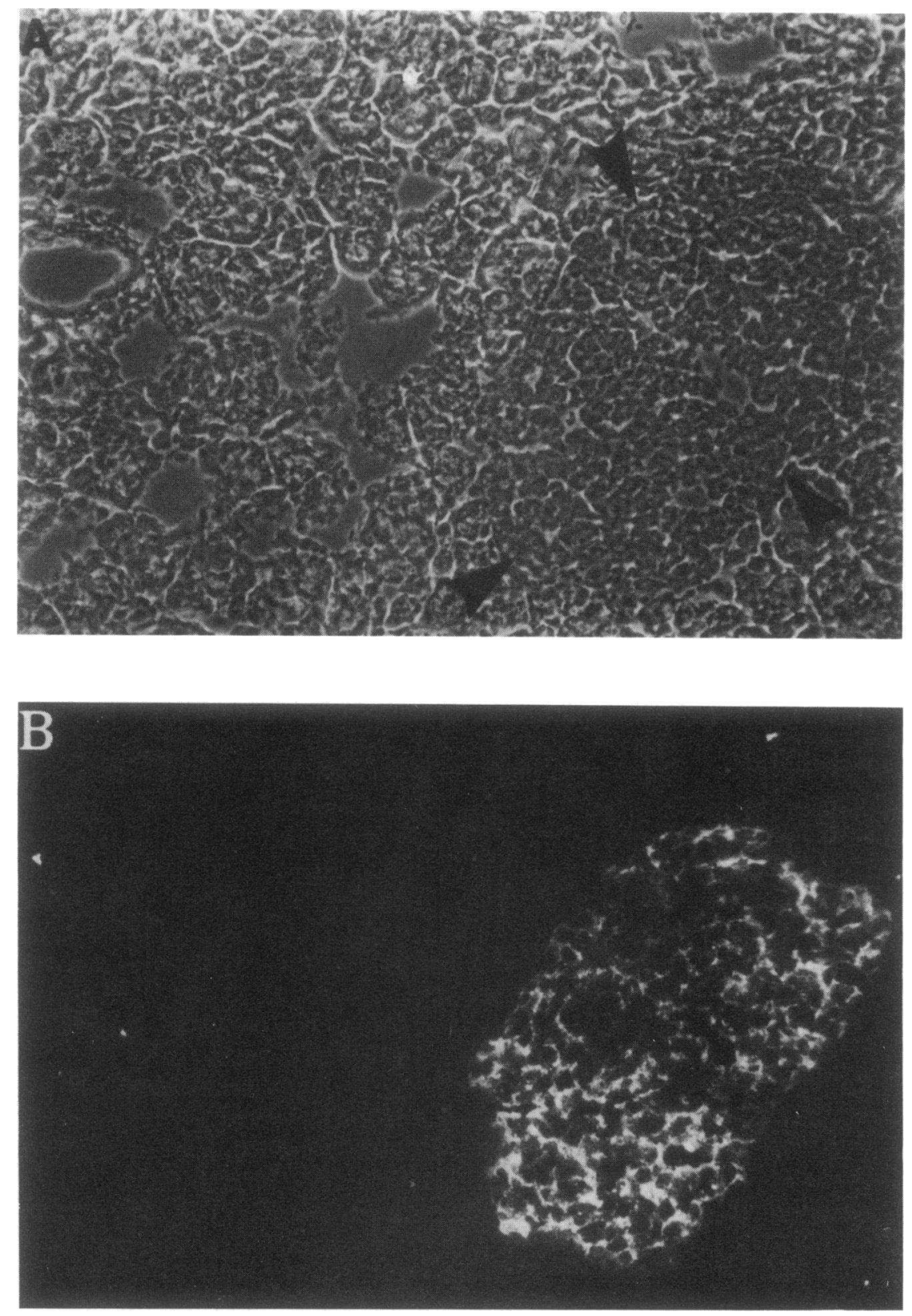

Figure 3. Indirect immunofluorescence staining of cryostat-sectioned rat pancreas incubated with antibody R2D6, followed by staining with FITC-conjugated goat anti-mouse immunoglobulins. $(A)$ Phasecontrast photomicrograph of an islet of Langerhans (outlined by arrowheads) that is surrounded by exocrine tissue. $\times 170$.

(B) Fluorescence photomicrograph of the same field as in $A$, showing the apparent surface staining pattern of the islet endocrine cells. $\times 170$. first incubated with either an irrelevant antibody or no antibody, exhibited no surface label on any cell.

Crossreactivity of R2D6 with other tissues was tested by indirect immunofluorescence studies of cryostat sections of other organs. As summarized in Table I, R2D6 binds to the adrenal medulla (Fig. $6 \mathrm{~A}$ ), the pars distalis (Fig. $6 \mathrm{~B}$ ), and the pars tuberalis of the pituitary, and to the myenteric plexus in both the stomach (not shown) and small intestine (Fig. $6 \mathrm{C}$ ), but not to the adrenal cortex, epithelial or smooth muscle cells in the stomach or small intestine, thyroid, thymus, cerebral cortex, cerebellum, RINm5F cells, or to $\mathrm{GH}_{3}$ cells. The pattern of reactivity of the previously described anti-islet monoclonal antibody A2B5 $(7,8,30)$ is similar (Table I), except that it also binds to the cerebellum (data not shown) and to thymic epithelial cells and RINm5F cells (references 8 and 31 , and present study).

Fluorescence-activated cell sorting. Dispersed rat islet cells, which were labeled with R2D6 by an indirect fluorescent antibody method, were sorted and analyzed by fluorescence-activated flow cytometry. During sorting, the population distributions with respect to cell size (light scatter) and antibody 


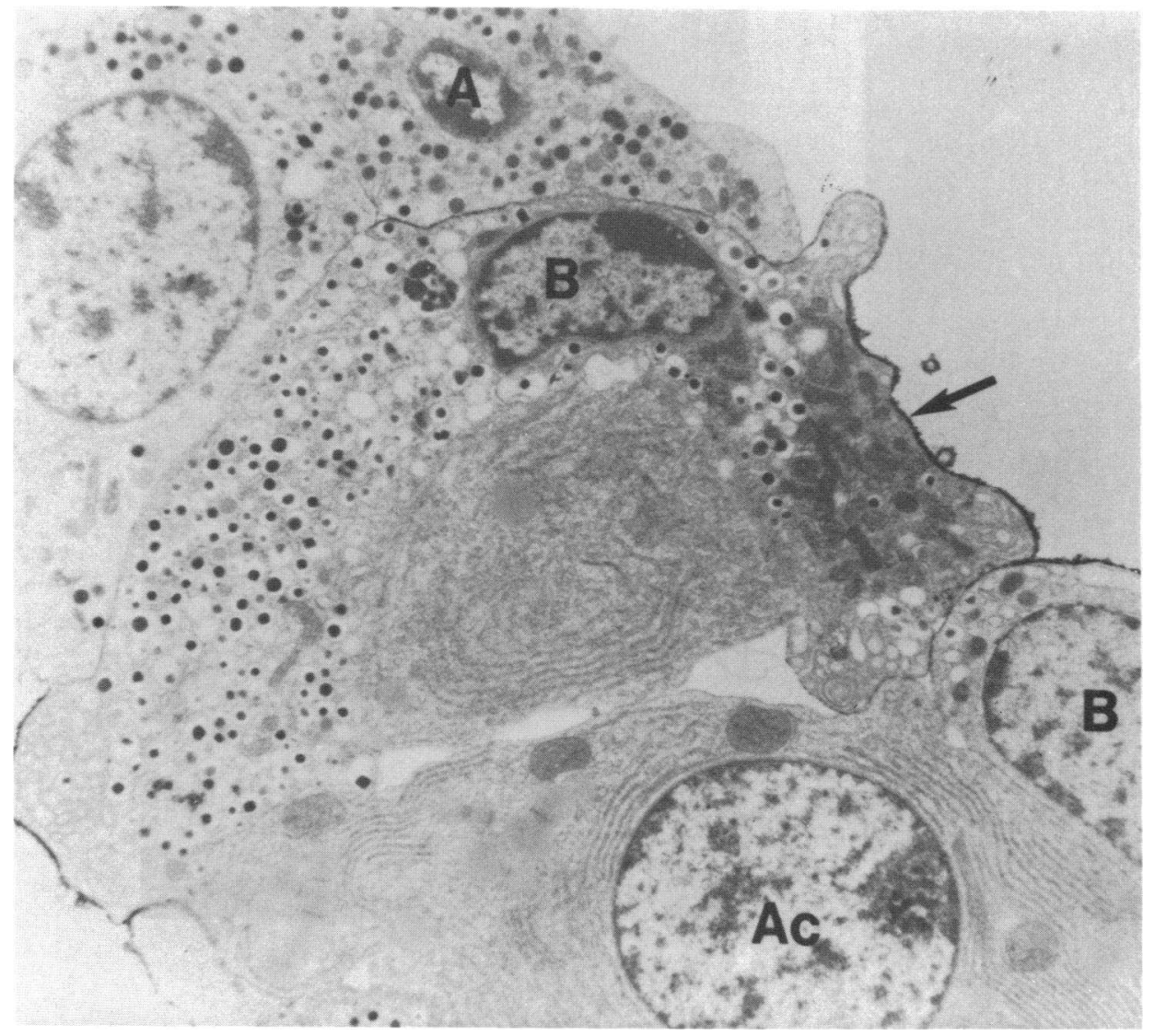

Figure 4. Electron micrograph of unfixed isolated rat islet incubated with antibody R2D6, which was subsequently localized by indirect peroxidase labeling (see Methods). The electrondense reaction product (arrow) is localized on the B cell surface but not on the $A$ cell or acinar cell. A, A cell; B, B cell; Ac, acinar cell. $\times 5,300$.

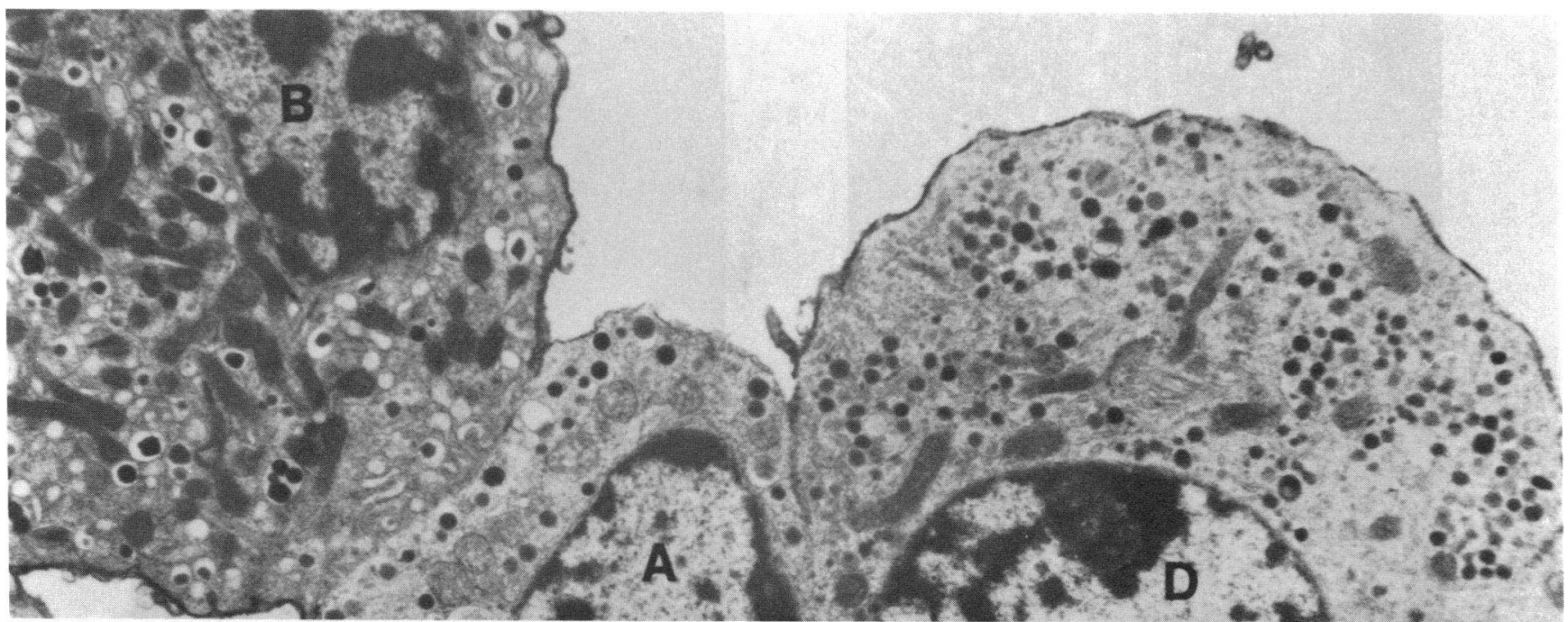

Figure 5. Electron micrograph of unfixed rat islet incubated with antibody A2B5, which was subsequently localized by the indirect peroxidase method. The electron-dense reaction product is localized on the cell surfaces of A, B, and D cells. A, A cell; B, B cell; D, D cell. $\times 6,200$. 

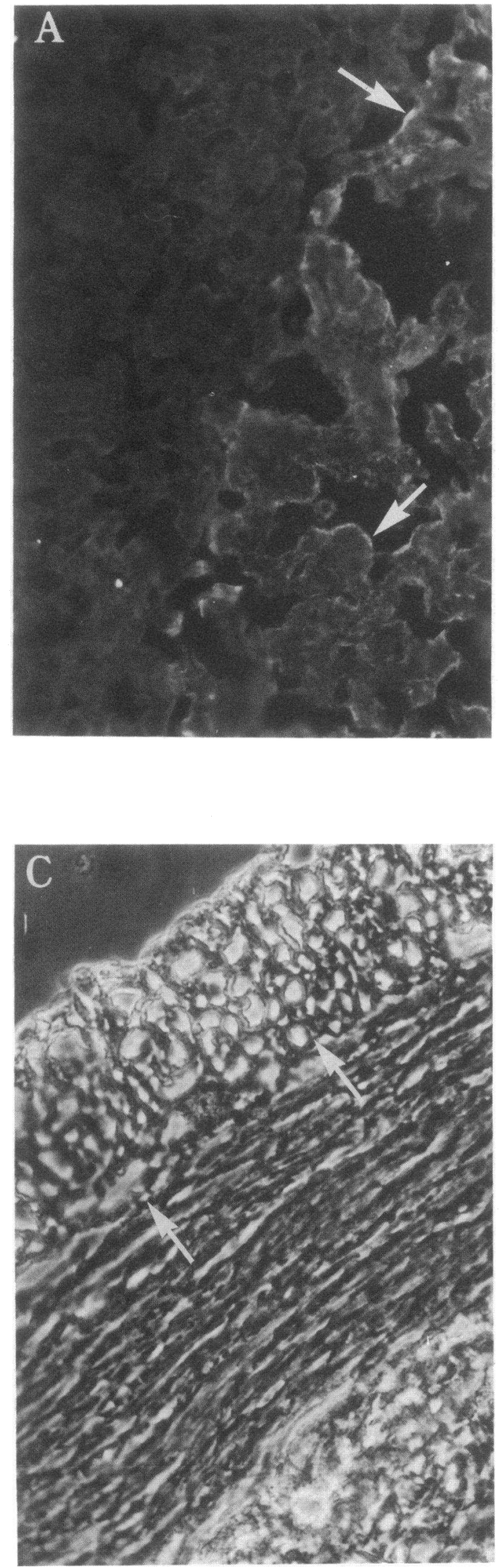

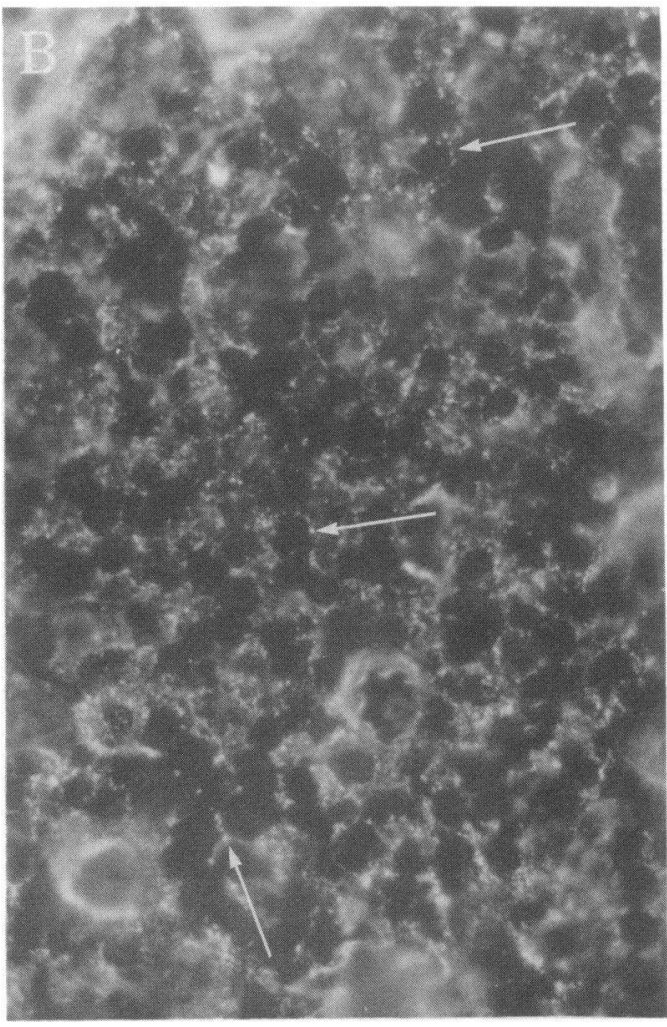

D

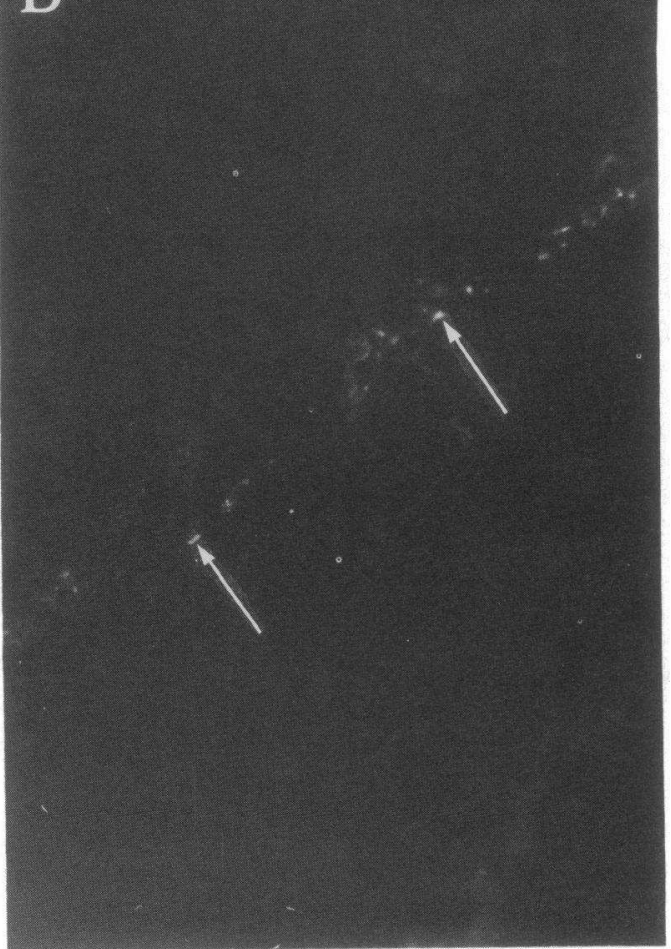


Table I. Binding of R2D6 and A2B5 to Nonpancreatic Cells (Indirect Immunofluorescence)

\begin{tabular}{|c|c|c|}
\hline & R2D6 & A2B5 \\
\hline \multicolumn{3}{|l|}{ Organ: } \\
\hline \multicolumn{3}{|l|}{ Adrenal } \\
\hline Medulla & + & + \\
\hline Cortex & - & - \\
\hline \multicolumn{3}{|l|}{ Pituitary } \\
\hline Pars distalis & + & + \\
\hline Pars tuberalis & + & + \\
\hline Pars nervosa & - & - \\
\hline Infundibular stem & - & - \\
\hline \multicolumn{3}{|l|}{ Stomach and small intestine } \\
\hline Myenteric plexus & + & + \\
\hline Epithelium & - & - \\
\hline Smooth muscle & - & - \\
\hline \multicolumn{3}{|l|}{ Thymus } \\
\hline Reticuloepithelial cells & - & + \\
\hline Medulla & - & - \\
\hline \multicolumn{3}{|l|}{ Brain } \\
\hline Cerebellum & - & + \\
\hline Cerebral cortex & - & - \\
\hline Thyroid & - & - \\
\hline \multicolumn{3}{|l|}{ Cell line: } \\
\hline $\mathrm{RIN}_{\mathrm{m}} 5 \mathrm{~F}$ (Rat insulinoma) & - & + \\
\hline $\begin{array}{l}\text { GH3 (Rat somatotropin-secreting } \\
\text { pituitary tumor) }\end{array}$ & - & - \\
\hline
\end{tabular}

R2D6- and A2B5-binding to nonpancreatic tissues and cell lines. Cryostat-sectioned organs or living cells were incubated with R2D6 or A2B5 followed by FITC-conjugated goat anti-mouse immunoglobulins. Reactivity with specific tissues or celllines is indicated as positive $(+)$ or negative $(-)$ compared with binding of an irrelevant control antibody.

labeling (fluorescence intensity) were analyzed and expressed as two-dimensional dot plots. In the unsorted population (Fig. $7 A$ ), there was no bimodal distribution on the basis of cell size and, furthermore, there was no correlation between fluorescent intensity and cell size. Fig. $7 B$ shows that, in the right sort, R2D6-positive (i.e., fluorescent) cells were specifically retrieved and R2D6-negative (i.e., nonfluorescent) cells were excluded.

The cell types comprising the R2D6-positive (right sort) and R2D6-negative (left sort) populations were identified ultrastructurally and compared with the unseparated population. As illustrated in Fig. 8, the R2D6-positive cells were greatly enriched for B cells (88-94\% of the right sort), whereas the R2D6-negative cells were enriched for A cells (79-90\% of the left sort), compared with the unseparated population, regardless of the purity of the starting islet preparation. The recoveries of viable B cells were $28 \pm 2.5 \%(n=3)$ of the B cells in the original dispersed islet population; for A cells, the recoveries were 39 and $55 \%$ in two experiments.

Antigen identification. The biochemical nature of the plasma membrane antigen recognized by R2D6 was first investigated by determining whether protease or neuraminidase treatment of rat islet cells inhibited subsequent R2D6-binding to the cells. As shown in Fig. 9, none of the proteases tested affects R2D6binding; however, neuraminidase treatment reduces subsequent R2D6-binding by $75 \%$. In order to test our initial hypothesis that the antigen recognized by R2D6 is a sialoglycoprotein with a cryptic polypeptide moiety (i.e., inaccessible to proteases), more extensive studies were performed. R2D6-affinity chromatography of radioiodinated islet cell surface proteins and of membrane proteins labeled metabolically with $\left[{ }^{35} S\right]$ methionine, and electrophoretic immunoblotting studies failed to reveal the existence of an R2D6-binding plasma membrane protein (data not shown).

A crude islet glycolipid fraction (DME) was then prepared by dichloromethane/methanol (2:1) extraction of islets. Solidphase RIA revealed that the R2D6-binding activity was quantitatively extracted into the solvent phase and was retained when the DME was dried and redissolved in either methanol or in PBS. After the DME was adsorbed to polyvinylchloride plates for RIA, R2D6-binding activity remained insensitive to protease $\left(500 \mu \mathrm{g} / \mathrm{ml}\right.$ Pronase at $60^{\circ} \mathrm{C}$ for $\left.24 \mathrm{~h}\right)$ but was totally destroyed by neuraminidase $\left(1 \mathrm{U} / \mathrm{ml}\right.$ at $37^{\circ} \mathrm{C}$ for $\left.1 \mathrm{~h}\right)$. R2D6-binding activity was unaffected by mild base hydrolysis.

The DME was chromatographed along with purified brain gangliosides on HPTLC plates in chloroform/methanol/2.5 N ammonia (60:40:9). After development of the plates, 5-mm sections of the silica gel were scraped and eluted with methanol. Solid-phase RIA of R2D6 binding to these fractions revealed that $>80 \%$ of the R2D6-binding activity migrates consistently as a sharply resolved peak with an $R_{f}$ of $0.54 \pm 0.07(n=3)$,
Figure 6. Indirect immunofluorescence staining of cryostat-sectioned adrenal gland, anterior pituitary, and small intestine, which were incubated with R2D6 followed by FITC-conjugated goat anti-mouse immunoglobulins. $(A)$ Fluorescence photomicrograph of adrenal medullary cells (arrows) and cortical cells (left); the corticomedullary boundary runs diagonally across the field, from upper right to lower left. $(B)$ Fluorescence photomicrograph of the pars distalis of the an- terior pituitary gland, showing peripheral staining (arrows) of secretory cells. $(C)$ phase-contrast photomicrograph of a cross-section of small intestine, with the location of the myenteric (Auerbach's) plexus indicated by arrowheads, between the outer longitudinal smooth muscle (above) and the inner circular smooth muscle (below). (D) Fluorescence photomicrograph of the same field as in $C$; the arrows are placed precisely at the same reference points as in $C . \times 430$. 
UNSORTED CELLS

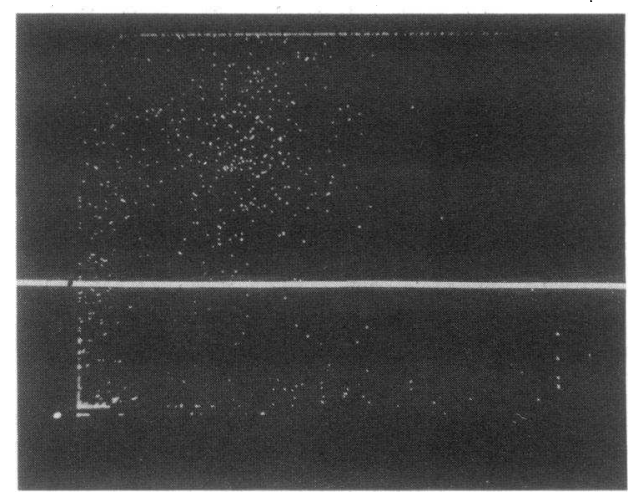

SORTED CELLS

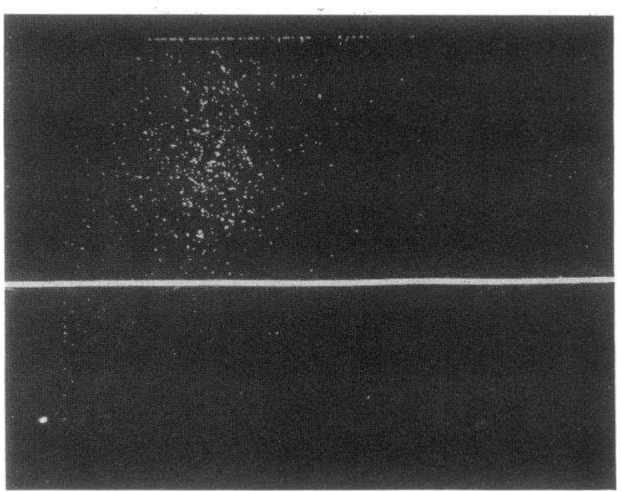

INCREASING LIGHT SCATTER $\rightarrow$

Figure 7. Two-dimensional fluorescence/light-scattering dot plots of unsorted rat islet cells and of sorted rat islet cells from a typical experiment. The vertical axis represents increasing fluorescent intensity, due to binding of R2D6, followed by FITC-conjugated goat antimouse immunoglobulins. The horizontal axis represents increasing light scattering, which is a function of cell size. The horizontal white line shows the level above which cells were considered to be specif-

nearly coincident with the purified brain ganglioside, GDla, which was used as a standard (Fig. 10). Two minor peaks were also present, both variable in magnitude, but never represented $>20 \%$ of the total R2D6-binding activity. The basis for this apparent heterogeneity remains to be determined.

The R2D6-binding activity in the DME eluted in the ganglioside fractions in each of several chromatographic systems. The antigen bound quantitatively to DEAE-Sephacel and was eluted in $0.2 \mathrm{M}$ ammonium acetate in methanol, which demonstrates that it was negatively charged. In addition, the antigen was stable to mild base hydrolysis, which provided evidence that the antigen was not a phospholipid, and bound to a reversephase C-18 Sep-Pak cartridge equilibrated in water. After a methanol wash of the cartridge, the antigen was quantitatively eluted with chloroform/methanol $(2: 1)$. The antigen also bound quantitatively to silicic acid in chloroform/methanol (4:1) and was eluted with methanol in the ganglioside fraction.

\section{Discussion}

We have demonstrated the existence of a plasma membrane antigen, $\mathrm{Ag}(\mathrm{R} 2 \mathrm{D} 6)$, which is $\mathrm{B}$ cell specific within the pancreas and which has an extrapancreatic distribution that is also highly restricted. $\mathrm{Ag}(\mathrm{R} 2 \mathrm{D} 6)$ was identified and characterized using a mouse monoclonal antibody, R2D6, which is an IgM raised against rat pancreatic islet cells. R2D6 also recognizes mouse cally stained (compared with an irrelevant control monoclonal antibody). In the unsorted population $(A)$, the cells are heterogeneous with respect to size (light scatter) and fluorescence as indicated by the distribution of cells both above and below the horizontal line. In the right, i.e. fluorescence-positive, sort $(B)$, the cells retrieved are nearly all fluorescent, with only a few falling below the horizontal line.

and guinea pig but not human or canine B cells. The B cell specific localization of $\mathrm{Ag}(\mathrm{R} 2 \mathrm{D} 6)$ within the pancreas was demonstrated by electron microscopic immunocytochemistry and was corroborated by ultrastructural analyses of R2D6-positive and R2D6-negative cells separated by FACS. R2D6 has no effect on glucose-stimulated insulin release in static incubation of whole islets or monolayer cultures of rat islets.

We have utilized R2D6 in FACS to prepare highly enriched populations of $B$ cells as well as to prepare A cells from either initially clean islet preparations (Fig. $8 A$, experiment 2 ) or from relatively impure islet preparations (Fig. $8 A$, experiments 1 and $3)$. The present method for FACS using R2D6 offers apparent advantages over previously published techniques (32-36), since purified B and A cell populations are obtained simultaneously and we use a separation parameter for which there is no overlap in the characteristics of the populations to be separated. This feature should allow reproducibility in other laboratories. The availability of purified B and A cell populations will facilitate studies of cellular interactions in islet endocrine cell secretory functions.

Our studies indicate that the determinant recognized by R2D6 is expressed by a glycoconjugate of the B cell plasma membrane. We have not succeeded in demonstrating R2D6-binding activity for any surface iodinated, metabolically-labeled, or unlabeled membrane protein. $\mathrm{Ag}(\mathrm{R} 2 \mathrm{D} 6)$ exhibits the following characteristics which are consistent with its identification as a gan- 

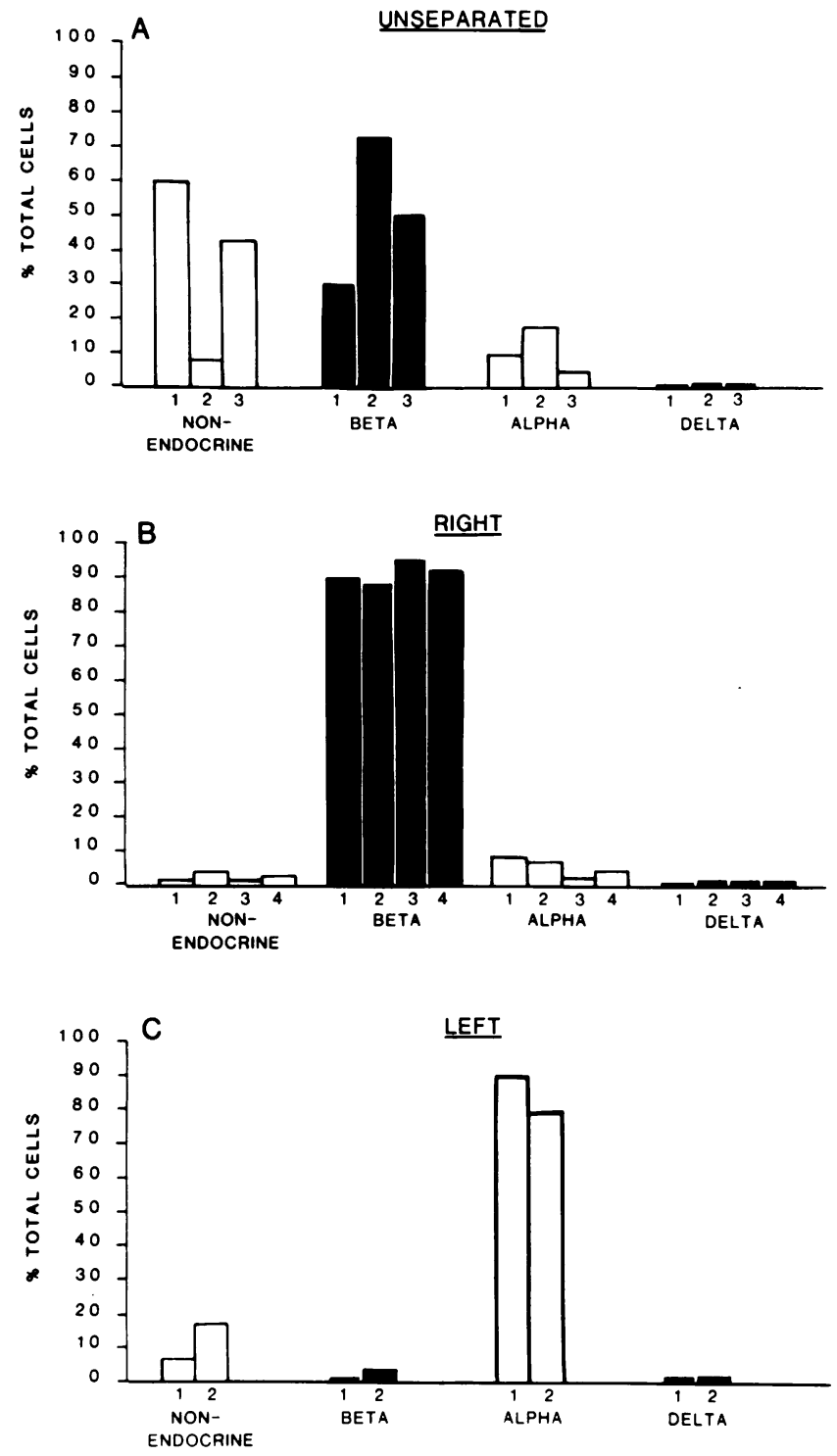

Figure 8. Cell type distribution in unseparated rat islet cells $(A)$ compared with the populations comprising the right (R2D6-positive) sort $(B)$ and the left (R2D6-negative) sort $(C)$ after FACS. The vertical axis depicts the percentage of cells identified as each cell type by using ultrastructural criteria. The numbers under the bars along the horizontal axis each depict an experiment number, e.g., all bars labeled " 1 " are from the same experiment. The number of live cells counted in each population per experiment were as follows: unseparated, 192-393; right sort (R2D6-positive), 330-651; and left sort (R2D6-negative), 76-196. Sufficient cells to analyze were retrieved from all three populations (unseparated, right, and left sorts) only in experiments 1 and 2.

glioside: (a) it is quantitatively extractable in 2:1 chloroform/ methanol and, after extraction, is both methanol- and PBSsoluble; $(b)$ its reactivity to R2D6 is decreased $75-100 \%$ by neuraminidase but is unaffected by proteases, whether the antigen is treated in its native configuration in the plasma membranes of intact cells or in a solvent-extracted form (DME) adsorbed to solid phase; $(c)$ its reactivity to R2D6 is unaffected by mild base hydrolysis (which hydrolyzes phospholipids); $(d)$ it migrates on HPTLC plates developed in 60:40:9 chloroform/methanol/ $2.5 \mathrm{~N}$ ammonia as a major peak with an $R_{\mathrm{f}}$ of $0.54 \pm 0.07$, a position that is nearly coincident with that of purified GDla; (e) it elutes with ganglioside fractions upon DEAE-Sephadex, $\mathrm{C}_{18}$ Sep-Pak, and silicic acid chromatography.

Although gangliosides in normal islet cells have not been directly analyzed, islet membrane components with ligandbinding properties similar to those of particular gangliosides found in other tissues have been demonstrated. Thus, cholera toxin activates adenylate cyclase in pancreatic islets (37), resulting in insulin secretion, and binds to a ganglioside (GM1) that is present in the central nervous system and possibly many other tissues (38). Similarly, tetanus toxin also binds to islet endocrine cells (8) and, again, its receptors in the central nervous system seem to be gangliosides (Gdla and Gtlb; reference 38 ). Finally, monoclonal antibody A2B5, which has been reported to recognize a ganglioside in embryonic chick neural retina and in

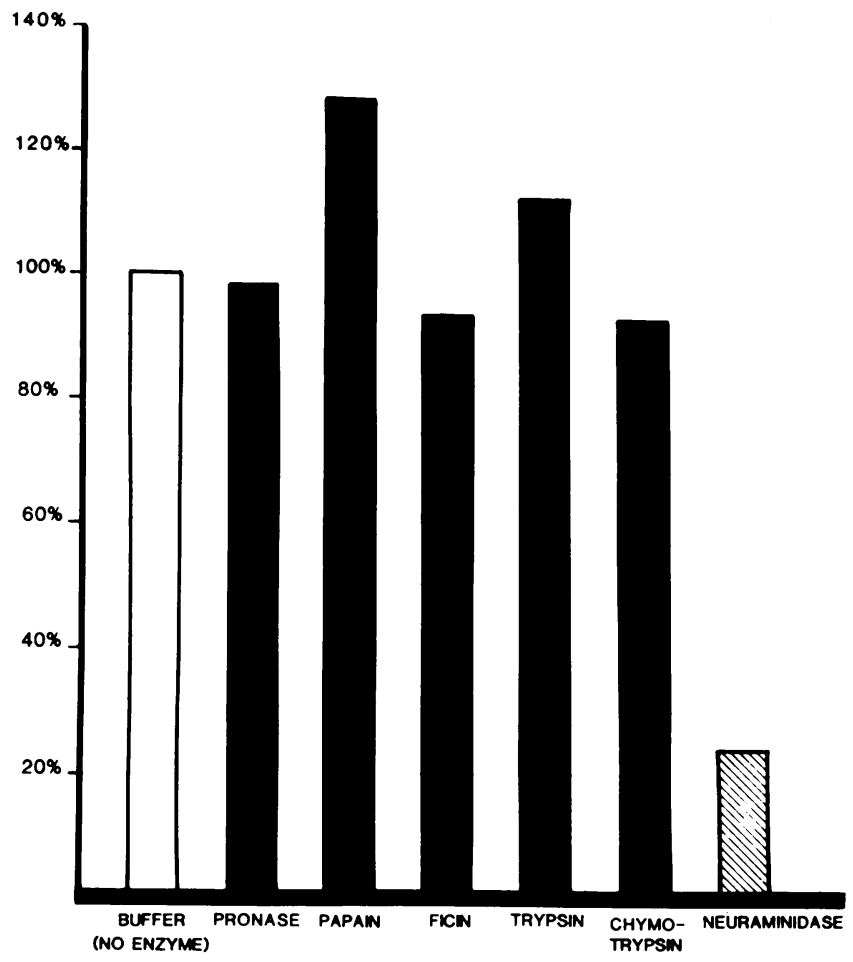

Figure 9. Effects of enzyme treatments on R2D6 binding to rat islet cells. Values are expressed on the ordinate as the percentage of control cpm ( ${ }^{125}$ I-sheep anti-mouse immunoglobulin) bound after R2D6 binding to enzyme-treated cells. Protease incubations were carried out at $500 \mu \mathrm{g}$ protease $/ \mathrm{ml}$ and $10^{6} \mathrm{cells} / \mathrm{ml}$; neuraminidase incubations were carried out at $1 \mathrm{U} / \mathrm{ml}$ and $2 \times 10^{6} \mathrm{cells} / \mathrm{ml}$. 


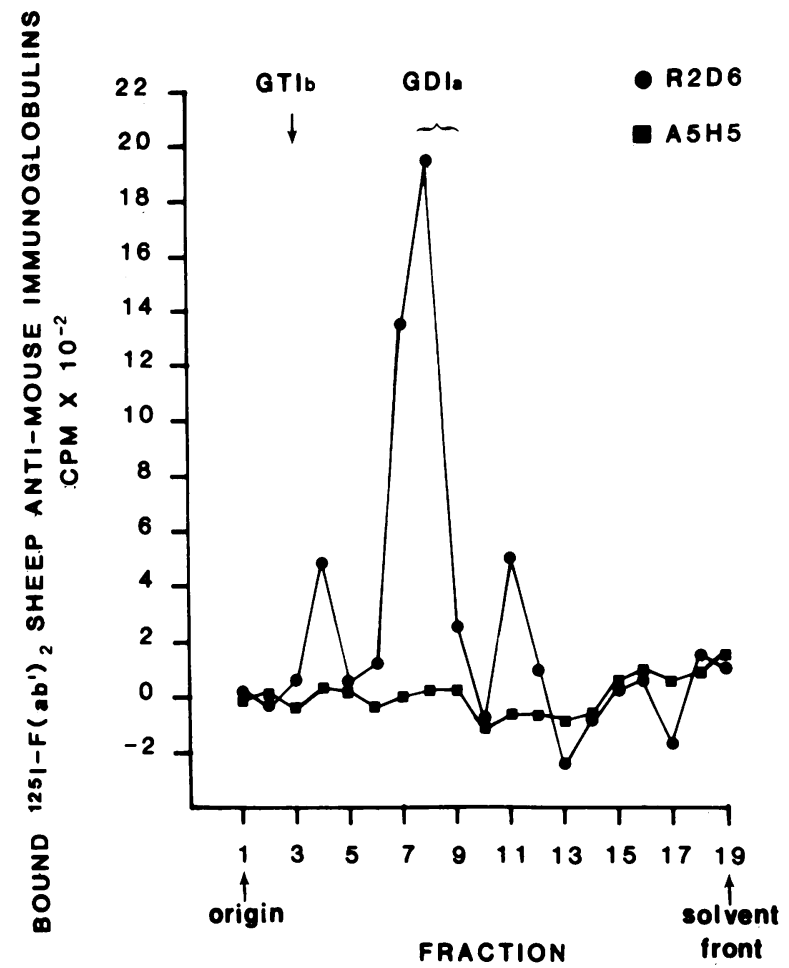

Figure 10. R2D6 vs. A5H5 binding to HPTLC fractions of rat islet glycolipids. A DME of 200 rat islets was chromatographed by HPTLC on a 10-cm Merck silica gel 60 plate (prerun) and developed in chloroform/methanol/2.5 N ammonia (60:40:9). Silica gel sections $(5 \mathrm{~mm})$ were scraped and eluted with methanol. The eluates were assayed for binding of R2D6 or A5H5 (an irrelevant monoclonal IgM) by solid-phase RIA, in which monoclonal antibody bound to adsorbed eluate was detected with ${ }^{125}$ I-labeled $\left(\mathrm{Fab}^{\prime}\right)_{2}$ fragments of sheep anti-mouse immunoglobulins. Antibody binding is expressed for each fraction (horizontal axis) as $\mathrm{cpm}$ of ${ }^{125} \mathrm{I}$ (vertical axis). The majority ( $\geqslant 80 \%$ of the R2D6-binding activity consistently migrated as a single peak with an $R_{f}$ of 0.5 . The positions of purified brain ganglioside standards, GT1b and GDla, after chromatography in an adjacent lane on the same HPTLC plate, are indicated. Each value shown is the mean of two duplicate determinations.

human and bovine brain $(7,39)$, also binds to pancreatic islet endocrine cells. Whether these specific oligosaccharide receptors are present in islets as gangliosides remains to be determined.

We have shown that the determinant recognized by A2B5 $(7,8,30,31)$ clearly differs from that recognized by R2D6. A2B5 has a broader specificity, both within islets (it binds to $A$ and $D$ cells, in addition to $B$ cells) and in other tissues. Competitive binding experiments using radioiodinated antibodies show that unlabeled A2B5 inhibits the bindings of labeled R2D6 to rat islets but unlabeled R2D6 does not influence the binding of labeled A2B5 (Fig. 2). This nonreciprocal inhibition suggests that the determinant recognized by R2D6 is spatially related to the determinant recognized by $A 2 B 5$, either on the same glycoconjugate or on different "neighboring" species, or that A2B5 recognizes several gangliosides in islets as it does in human brain (39) and that some but not all of these are recognized by R2D6. The relationship of $\mathrm{Ag}(\mathrm{R} 2 \mathrm{D} 6)$ to other $\mathrm{B}$ cell plasma membrane glycolipids and to targets for islet cell surface antibodies in diabetes mellitus remains to be defined.

The only extrapancreatic localizations of $\mathrm{Ag}(\mathrm{R} 2 \mathrm{D6}$ ) we have detected so far, by cell-binding RIAs and light microscopic immunocytochemical studies of a wide variety of rat tissues (Table I), are in the adrenal medulla, the anterior pituitary, and the myenteric plexus of the gastrointestinal tract. The expression of such a highly specialized cell surface antigen by both B cells and these other neurosecretory tissues may be related to a shared physiological property.

It is of special interest that a cell surface determinant on one particular cell-type within the pancreatic islet, viz the B cell, can be shared by other neurosecretory cells. Monoclonal antibodies reactive with multiple organs, including the islets of Langerhans, have been previously produced by fusion of splenic leukocytes from reovirus Type I infected mice $(40,41)$ with mouse myeloma cells, or by fusion of peripheral blood lymphocytes from patients with insulin-requiring diabetes mellitus and other autoimmune abnormalities with mouse or human myeloma cells (42). It remains to be shown, however, whether extrapolation of these observations, and our findings that at least one antigenic determinant is present on cell surfaces in multiple endocrine organs, provide an explanation for circulating antibodies that have multiple organ reactivity and that are found in some patients with recent-onset diabetes mellitus $(43,44)$. It will be of great interest to know ultimately whether the organ crossreactivity of R2D6 represents the presence of identical antigens in different endocrine tissues or, instead, represents the recognition of a common determinant carried by different, possibly unrelated molecules.

\section{Acknowledgments}

The authors wish to thank Dr. Philip Halban, Institute of Clinical Biochemistry, University of Geneva, Switzerland, for assistance and advice. We also wish to acknowledge the expert technical assistance of Jack Noel, Janet Preyer, Juana Alvarez, Olga Garcia, Argelia Novoa, and Seth Troner, as well as the invaluable secretarial assistance of Margaret Collado, Catherine Schmitt, and Nora Viguie.

This investigation was supported by the Diabetes, Metabolism and Endocrinology Training National Research Service Award grant 5T32AM07346-5, and grant AM25802-04, CA35377-01 from the National Institutes of Health, and by the Diabetes Research Institute Foundation.

\section{References}

1. Lernmark, A., B. Hagglof, Z. Freedman, J. Irvine, J. Ludvigsson, and G. Holmgren. 1981. A prospective analysis of antibodies reacting 
with pancreatic islet cells in insulin-dependent diabetic children. Diabetologia. 20:471-474.

2. Pujol-Borrell, R., E. L. Khoury, and G. F. Bottazzo. 1982. Islet cell surface antibodies in type I (insulin-dependent) diabetes mellitus: use of human fetal pancreas cultures as substrate. Diabetologia. 22:89-95.

3. Van De Winkel, M., G. Smetz, W. Gepts, and D. Pipeleers. 1982. Islet cell surface antibodies from insulin-dependent diabetics bind specifically to pancreatic B cells. J. Clin. Invest. 70: 41-49.

4. Dobersen, M. J., and J. E. Scharff. 1982. Preferential lysis of pancreatic B-cells by islet cell surface antibodies. Diabetes. 31:459-462.

5. Kanatsuna, T., S. Baekkeskov, A. Lernmark, and J. Ludvigsson. 1983. Immunoglobulin from insulin-dependent diabetic children inhibits glucose-induced insulin release. Diabetes. 32:520-524.

6. Baekkeskov, S., J. H. Nielsen, B. Marner, T. Bilde, J. Ludvigsson, and A. Lernmark. 1982. Autoantibodies in newly diagnosed diabetic children immunoprecipitate specific human pancreatic islet cell proteins. Nature (Lond.). 298:167-169.

7. Eisenbarth, G. S., F. S. Walsh, and M. Nirenberg. 1979. Monoclonal antibody to a plasma membrane antigen of neurons. Proc. Natl. Acad. Sci. USA. 76:4913-4917.

8. Eisenbarth, G. S., K. Shimizu, M. A. Bowring, and S. Wells. 1982. Expression of receptors for tetanus toxin and monoclonal antibody A2B5 by pancreatic islet cells. Proc. Natl. Acad. Sci. USA., 79:50665070.

9. Crump, M. A., R. Scearce, M. Dobersen, W. Kortz, and G. S. Eisenbarth. 1982. Production and characterization of a cytotoxic monoclonal antibody reacting with rat islet cells. J. Clin. Invest. 70:659-666.

10. Shulman, M., C. D. Wilde, and G. Kohler. 1978. A better cell line for making hybridomas secreting specific antibodies. Nature (Lond.). 276:269-270.

11. Hayry, P., T. H. Totterman, and A. Ranki. 1977. Lack of subclass selection during density purification of human lymphocytes. Clin. Exp. Immunol. 28:341-346.

12. Lacy, P. E., and M. Kostianovsky. 1967. Method for the isolation of intact islets of Langerhans from the rat pancreas. Diabetes. 16:35-39.

13. Meda, P., E. L. Hooghe-Peters, and L. Orci. 1980. Monolayer cultures of adult pancreatic islet cells on osmotically disrupted fibroblasts. Diabetes. 29:497-500.

14. Galfre, G., and C. Milstein. 1981. Preparation of monoclonal antibodies: strategies and procedures. Methods Enzymol. 73:3-46.

15. Kennett, R. H. 1980. Fusion by centrifugation of cells suspended in polyethylene glycol. In Monoclonal Antibodies. Hybridomas: A New Dimension in Biological Analyses. R. H. Kennett, T. J. McKearn, and K. B. Bechtol, editors. Plenum Press, New York. 365-367.

16. McKearn, T. J. 1980. Cloning of hybridoma cells by limiting dilution in fluid phase. In Monoclonal Antibodies. Hybridomas: A New Dimension in Biological Analyses. R. H. Kennett, T. J. McKearn, and K. B. Bechtol, editors. Plenum Press, New York. 374.

17. Coller, H. A., and B. S. Coller. 1983. Statistical analysis of repetitive subcloning by the limiting dilution technique with a view toward ensuring hybridoma monoclonality. Hybridoma. 2:91-96.

18. Jonak, Z. L. 1980. Isolation of monoclonal antibodies from supernatant by $\left(\mathrm{NH}_{4}\right)_{2} \mathrm{SO}_{4}$ precipitation. In Monoclonal Antibodies. Hybridomas: A New Dimension in Biological Analyses. R. H. Kennett, T. J. McKearn, and K. B. Bechtol, editors. Plenum Press, New York. 405-406.
19. Tsu, T. T., and L. A. Herzenberg. 1980. Solid-phase radioimmune assays. In Selected Methods in Cellular Immunology. B. B. Mishel and S. M. Shiigi, editors. W. H. Freeman and Co., San Francisco, CA. 373397.

20. Eisenbarth, G. S., B. F. Haynes, J. A. Schroer, and A. S. Fauci. 1980. Production of monoclonal antibodies reacting with peripheral blood mononuclear cell surface differentiation antigens. J. Immunol. 124:1237-1244.

21. McKearn, T. J. 1980. ${ }^{51} \mathrm{Cr}$ release cytotoxicity assay. In Monoclonal Antibodies. Hybridoma: A New Dimension in Biological Analyses. R. H. Kennett, T. J. McKearn, and K. B. Bechtol, editors. Plenum Press, New York. 393-394.

22. Alejandro, R., F. L. Shienvold, S. V. Hajek, U. Ryan, J. Miller, and D. H. Mintz. 1982. Immunocytochemical localization of HLA-DR in human islets of Langerhans. Diabetes. 31(Suppl4):17-22.

23. Hubbard, A. L., and Z. A. Cohn. 1975. Externally disposed plasma membrane proteins. I. Enzymatic iodination of mouse L cells. J. Cell Biol. 64:438-460.

24. Hughes, E. N., and J. T. August. 1981. Characterization of plasma membrane proteins identified by monoclonal antibodies. J. Biol. Chem. 256:664-671.

25. Lampson, L. 1980. Immunoprecipitation with monoclonal antibodies. In Monoclonal Antibodies. Hybridomas: A New Dimension in Biological Analyses. R. H. Kennett, T. J. McKearn, and K. B. Bechtol, editors. Plenum Press, New York. 395-397.

26. Laemmli, V. K. 1970. Cleavage of structural proteins during the assembly of the head of the bacteriophage T4. Nature (Lond.). 227:680685.

27. Erickson, P. F., L. N. Miner, and R. S. Lasher. 1982. Quantitative electrophoretic transfer of polypeptides from SDS polyacrylamide gels to nitrocellulose sheets: a method for their re-use in immunoautoradiographic detection of antigens. J. Immunol. Methods. 51:241-249.

28. Kundu, S. K., and A. Suzuki. 1981. Simple micromethod for the isolation of gangliosides by reversed-phase chromatography. J. Chromatogr. 224:249-256.

29. Magnani, J. L., B. Nilsson, M. Brockhaus, D. Zopf, Z. Steplewski, H. Koprowski, and U. Ginsburg. 1982. A monoclonal antibody-defined antigen associated with gastrointestinal cancer is a ganglioside containing sialylated lacto-N-fucopentaose II. J. Biol. Chem. 257:14365-14369.

30. Shimizu, K., G. S. Eisenbarth, M. A. Bowring, and S. A. Wells. 1982. Expression of receptors for tetanus toxin and monoclonal antibody A2B5 on "APUD" cells and "APUD" cell tumors. Surg. Forum. 32:419421.

31. Haynes, B. F., K. Shimizu, and G. S. Eisenbarth. 1983. Identification of human and rodent thymic epithelium using tetanus toxin and monoclonal antibody A2B5. J. Clin. Invest. 71:9-14.

32. Rabinovitch, A., T. Russell, F. Shienvold, J. Noel, N. Files, Y. Patel, and M. Ingram. 1982. Preparation of rat islet B-cell enriched fractions by light-scatter flow cytometry. Diabetes. 31:939-943.

33. Fletcher, D. J., W. M. Grogan, E. Barras, and G. C. Weir. 1983. Hormone release by islet B cell-enriched and A and D cell-enriched populations prepared by flow cytometry. Endocrinology. 113:1791-1798.

34. Nielsen, D. A., A. Lernmark, M. Berelowitz, G. D. Bloom, and D. F. Steiner. 1982. Sorting of pancreatic islet cell sub-populations by light scattering using a fluorescence-activated cell sorter. Diabetes. 31:299_ 306.

35. Van De Winkel, M., E. Maes, and D. Pipeleers. 1982. Islet cell analysis and purification by light scatter and autofluorescence. Biochem. Biophys. Res. Commun. 107:525-532. 
36. Pipeleers, D. G., and M. A. Pipeleers-Marichal. 1981. A method for the purification of single A, B and D cells and for the isolation of coupled cells from isolated rat islets. Diabetologia. 20:654-663.

37. Wollheim, C. B., B. Blondel, and W. G. Sharp. 1974. Effect of cholera toxin on insulin release in monolayer cultures of the endocrine pancreas. Diabetologia. 10:783-787.

38. Fishman, P. H. 1982. Role of membrane gangliosides in the binding and action of bacterial toxins. J. Membr. Biol. 69:85-97.

39. Fredman, P., J. L. Magnani, G. B. Grunwald, G. D. Trisler, M. Nirenberg, and V. Ginsburg. 1983. Monoclonal antibodies A2B5, 105, and $18 \mathrm{~B} 8$ react with many gangliosides in neuronal tissue. Glycoconjugates. Proc. Int. Symp. Glycoconjugates, 7th, Lund, Sweden. 242A. (Abstr.)

40. Haspel, M. V., T. Onodera, B. S. Prabhakar, M. Horita, H. Suzuki, and A. L. Notkins. 1983. Virus-induced autoimmunity: mono- clonal antibodies that react with endocrine tissues. Science (Wash. DC). 220:304-306.

41. Haspel, M. V., T. Onodera, B. S. Prabhakar, P. R. McClintock, K. Essani, U. R. Ray, S. Yagihashi, and A. L. Notkins. 1983. Multiple organ-reactive monoclonal autoantibodies. Nature (Lond.). 304:73-76.

42. Satoh, J., B. S. Prabhakar, M. V. Haspel, F. Ginsberg-Fellner, and A. L. Notkins. 1983. Human monoclonal autoantibodies that react with multiple endocrine organs. N. Engl. J. Med. 309:217-220.

43. Irvine, W. J. 1980. Autoimmunity in endocrine disease. Recent Prog. Horm. Res. 36:509-556.

44. Mirakian, R., G. F. Bottazzo, A. G. Cudworth, C. A. Richardson, and D. Doniach. 1982. Autoimmunity to anterior pituitary cells and the pathogenesis of insulin-dependent diabetes mellitus. Lancet. I:755759. 